\title{
The Effect of Service Quality on Loyalty Through Patient Satisfaction in Outpatient of Hospital X, Malang
}

\author{
Moh.Sholeh ${ }^{1}$, Djazuly Chalidyanto ${ }^{2}$ \\ ${ }^{1}$ Ccorrespondence Author: moh.sholeh-2019@fkm.unair.ac.id \\ ${ }^{1}$ Departement of Administration and Health Policy, Universitas Airlangga, Surabaya Jalan Dr.Ir.H Soekarno, Indonesia \\ 2Departement of Administration and Health Policy, Universitas Airlangga,Surabaya Jalan Dr.Ir.H Soekarno, Indonesia
}

\begin{tabular}{lll}
\hline I N D E X I N G & A B S T R AC T \\
\cline { 2 - 3 } Keywords: & The quality of service assessed by patients is an important basis for determining \\
Satisfaction; & patient satisfaction and loyalty. There has been a decrease in the number of general \\
Loyalty; & patient visits at Outpatient Hospital X from $2018-2019$ amounting to 113 people and \\
Outpatient. & $55 \%$. This study was conducted to determine the effect of service quality on \\
& satisfaction, the effect of service quality on loyalty, the effect of satisfaction on loyalty \\
and the effect of service quality on loyalty through satisfaction at X Hospital. The \\
research design used in this study was cross sectional study with a sample size of 30 \\
people. The results showed the effect of positive and significant service quality on \\
satisfaction (10,992), the effect of positive and significant service quality on \\
loyalty (3,270), the effect of positive and significant satisfaction on \\
loyalty $(2,176)$ and the effect of significant positive service quality on loyalty through \\
satisfaction (1,987). The influence of service quality on loyalty through patient \\
satisfaction (indirect) is the most dominant influence (0.886). Hospitals as health \\
service providers need to improve service quality in order to increase patient \\
satisfaction and loyalty.
\end{tabular}

Kata kunci:

Kualitas pelayanan;

Kepuasan;

Loyalitas, Rawat

jalan.

\begin{abstract}
Kualitas pelayanan yang dinilai oleh pasien merupakan dasar yang penting untuk menentukan kepuasan dan loyalitas pasien. Terjadi penurunan jumlah kunjungan pasien umum di Rawat Jalan RS X dari tahun 2018 - 2019 sebesar 113 orang dan angka kepuasan pasien yang belum memenuhi standar pada tahun 2019 sebesar $55 \%$. Penelitian ini dilakukan untuk mengetahui pengaruh kualitas pelayanan terhadap kepuasan, pengaruh kualitas pelayanan terhadap loyalitas, pengaruh kepuasan terhadap loyalitas dan pengaruh kualitas pelayanan terhadap loyalitas melalui kepuasan di RS X. Desain penelitian yang digunakan dalam penelitian ini adalah cross sectional study dengan jumlah sampel 30 orang. Hasil penelitian menunjukkan pengaruh kualitas pelayanan positif dan signifikan terhadap kepuasan $(10,992)$, pengaruh kualitas pelayanan positif dan signifikan terhadap loyalitas $(3,270)$, pengaruh kepuasan positif dan signifikan terhadap loyalitas $(2,176)$ dan pengaruh kualitas pelayanan positif signifikan terhadap loyalitas melalui kepuasan $(1,987)$. Pengaruh kualitas pelayanan terhadap loyalitas melalui kepuasan pasien (indirect) adalah pengaruh paling dominan $(0,886)$. Rumah sakit sebagai penyedia layanan kesehatan perlu melakukan peningkatan kualitas pelayanan agar meningkatkan kepuasan dan loyalitas pasien.
\end{abstract}

(C) 2021 JMMR. All rights reserved

Article history: Received 2020-12-18; Revised 2021-02-15; Accepted 2021-06-11

\section{INTRODUCTION}

Good service quality is the key to the success of service providers, one of which is the hospital. Quality service indicators can be identified through security in providing health services, providing equal service, services based on actual evidence / conditions , prioritizing speed, efficiency and patient-focused services (Chandra, Ward, and Mohammadnezhad 2019). According to Fatima, et al (2018) and Johnson, et al (2016) the dimensions of service 
quality are the physical environment of the hospital, communication between health workers and patients, patient privacy and security ( patient safety), administrative processes and flow of patient visits.

The quality of service assessed by patients is an important basis for determining patient satisfaction and loyalty. Through patient satisfaction as an indicator of service outcome services will determine the success of service and quality of service in the hospital (Mohd and Chakravarty 2014). In a study conducted by Fufa, et al (2019) 294 patients were studied to determine service satisfaction with indicators of speed of service delivery time and provision of information about their illness. As a result, as many as $65 \%$ of the patients admitted to being satisfied with the speed of time providing outpatient services and $41.9 \%$ said they were satisfied with providing information about their illness. The dimensions in the study of patient satisfaction according to Raposo et al (2009) and Alryalat et al (2019) are satisfaction with the process, satisfaction with the results, satisfaction at the time of patient interaction with medical personnel, satisfaction with the time required during the service process visits, satisfaction with the overall cleanliness of the hospital.

The high level of loyalty is influenced by the level of patient satisfaction with the quality of services provided by the hospital. Characteristic attitudes and traits of patient loyalty in the hospital are based on a cross-sectional and recurring pattern of service use (Fitriani 2014). The dimensions for assessing patient loyalty according to Arab, et al (2012) are positive word of mouth about hospital services, recommending hospital services to others, a desire to reuse hospital services. This dimension of loyalty has an impact on loyalty as much as $54.8 \%$ of patients in the hospital, and as much as $45.2 \%$ of patient loyalty is influenced by other factors outside the dimension of loyalty (Yarmen et al. 2016).

Outpatient care is one of the health service facilities provided by the hospital. Outpatient services are often a major concern because the number of patients is greater than other health care facilities (Supartiningsih 2017). The number of general outpatient visits at RS X decreased by 113 patients, from 2018 to 2019. This was followed by a decrease in the patient satisfaction rate in 2018 by $60.5 \%$ and in 2019 by $55 \%$. This shows that there is a high probability that there is a relationship between patient dissatisfaction and the number of visits that have decreased due to the less than optimal quality of service.

The results of a preliminary study in the form of unstructured interviews with 10 outpatients, showed that $60 \%$ of patients were dissatisfied with outpatient services and $40 \%$ of patients were satisfied. The dissatisfaction felt by patients is due to waiting for a doctor's examination that is too long, which is more than 1 hour, the lack of information provided by health workers to patients about the patient's illness and the lack of communication between health workers and patients. A number of $100 \%$ of patients state the reason for returning to the hospital and undergoing an outpatient examination because of problems or complaints that they feel do not go away, so that patients routinely carry out control and treatment according to doctor's recommendations and the distance between the house and the hospital is close. 
This research was conducted to determine the effect of service quality on satisfaction, the effect of service quality on loyalty, the effect of satisfaction on loyalty and the effect of service quality on loyalty through satisfaction. The results of this study are expected to provide a reference in an effort to improve service quality to increase patient satisfaction and maintain patient loyalty in the hospital.

\section{RESEARCH METHOD}

The research design used in this study was observational with quantitative research methods and a cross sectional study approach. This research was conducted at Outpatient Hospital X Malang Regency. The variables studied were service quality consisting of 5 indicators, satisfaction consisting of 5 indicators and loyalty consisting of 3 indicators (Picture 1). Data were collected by distributing questionnaires directly and google forms which were carried out for one week from June i to June 2020. The questionnaire was developed based on research by Fatima, et al (2018); Johnson, et al (2016); Raposo, et al (2009); Puspitasari and Edris (2011); and Arab, et al (2012). The questionnaire was tested for validity and reliability first using Pearson's correlation and Cronbach's Alpha.

Sampling was done by using purposive sampling technique with inclusion criteria in taking the questionnaire directly, are general patients who come for treatment more than 3 times at Outpatient Hospital X Malang Regency, aged 18 years or more and have the ability to read and write. The inclusion criteria in collecting questionnaire data via google form are: 1). Age range 18 years to 40 years; 2). Have visited X Hospital outpatient at least 3 times in the last 3 months. The exclusion criteria in this study were patients who refused to be respondents, in data retrieval via google form, namely patients over 40 years of age and patients who visited outpatient care less than 3 times. The number of samples in this study used the Roscoe formula, namely $10 \mathrm{x}$ the number of variables in order to obtain a total of 30 respondents. The data analysis used was Partial Least Square (PLS).

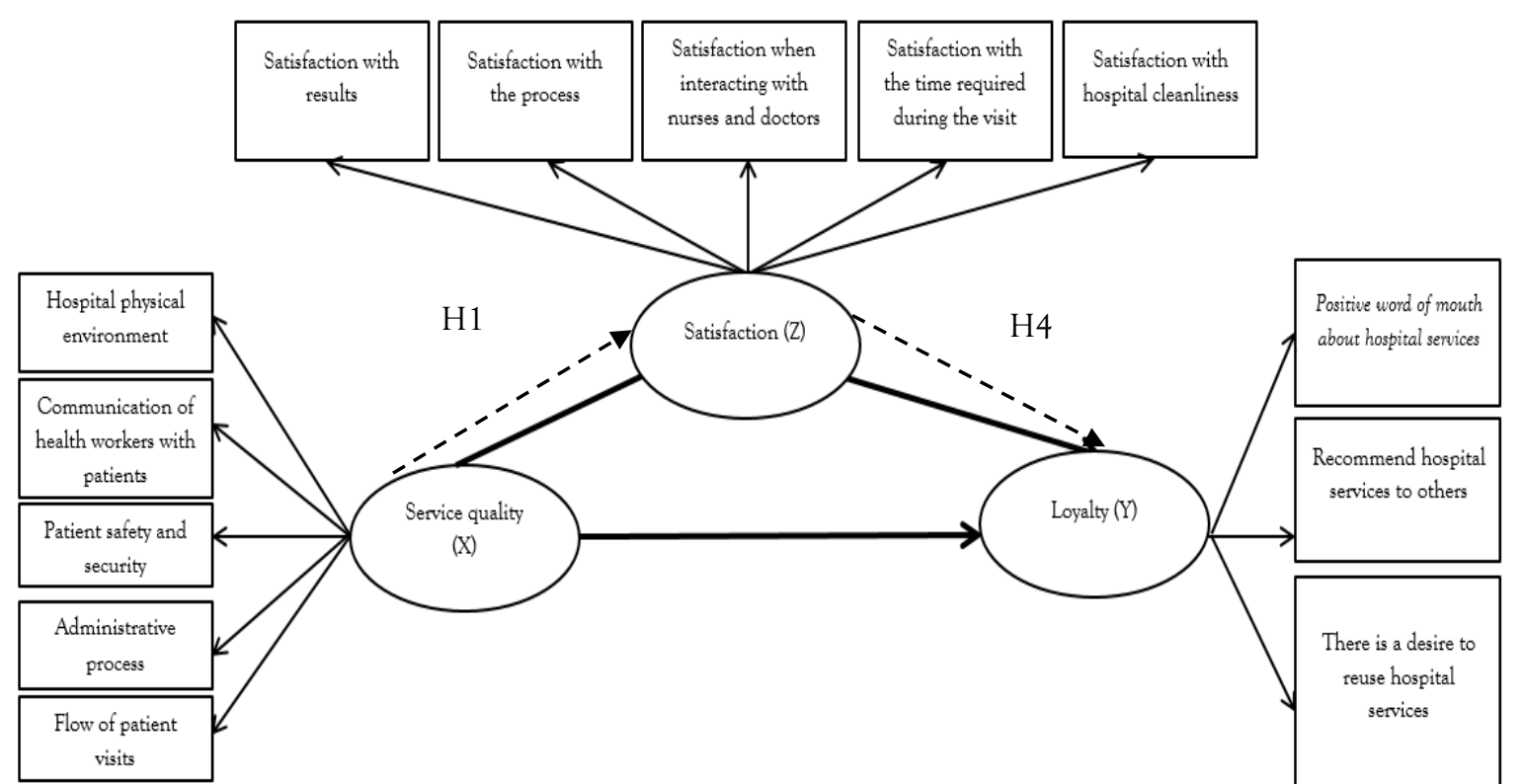




\section{Picture 1. Concept Framework}

Source: (Fatima, Malik, and Shabbir 2018)(Johnson, Russell, and White 2016)(Raposo, Alves, and Duarte 2009)(Alryalat et al. 2019)(Arab et al. 2012)(Puspitasari and Edris 2011)

\section{RESULT AND DISCUSSION}

Respondents in this study amounted to 30 people. The characteristics of respondents in this study were the majority of them were female $(63.3 \%)$ with an age range of $46-65$ years (40\%). From the latest educational information, it is known that most patients are primary school graduates $(43.3 \%)$ and work as private employees (30\%). The number of patient visits during treatment at Outpatient Hospital X Malang Regency was more than 3 times (53.3\%) (Table 1).

Table 1. Characteristics of Respondents

\begin{tabular}{|c|c|c|}
\hline Respondent Characteristics & Frequency & Percentage (\%) \\
\hline \multicolumn{3}{|l|}{ Gender } \\
\hline - Male & 11 & $36.7 \%$ \\
\hline - Women & 19 & $63.3 \%$ \\
\hline \multicolumn{3}{|l|}{ Age } \\
\hline - $\quad<26$ years & 4 & $13.3 \%$ \\
\hline - $\quad 26-45$ years & 11 & $36.7 \%$ \\
\hline - $\quad 46-65$ years & 12 & $40 \%$ \\
\hline - $\quad>65$ years & 3 & $10 \%$ \\
\hline \multicolumn{3}{|l|}{ Education } \\
\hline - $\quad \mathrm{SD}$ & 13 & $43.3 \%$ \\
\hline - Junior High & 2 & $6.7 \%$ \\
\hline - $\quad \mathrm{SMA} / \mathrm{SMK}$ & 9 & $30.0 \%$ \\
\hline - $\quad$ D3 & 1 & $3.3 \%$ \\
\hline S1 & 5 & $16.7 \%$ \\
\hline \multicolumn{3}{|l|}{ Profession } \\
\hline - Labor & 2 & $6.7 \%$ \\
\hline - IRT & 3 & $10.0 \%$ \\
\hline - General employees & 9 & $30.0 \%$ \\
\hline - College student & 1 & $3.3 \%$ \\
\hline - Civil servants & 2 & $6.7 \%$ \\
\hline - Farmer & 7 & $23.3 \%$ \\
\hline - entrepreneur & 6 & $20.0 \%$ \\
\hline \multicolumn{3}{|l|}{ Number of Visits } \\
\hline - 3 times & 22 & $22 \%$ \\
\hline
\end{tabular}




\begin{tabular}{ccc}
\hline Respondent Characteristics & Frequency & Percentage (\%) \\
\hline$\bullet>3$ times & 55 & $55 \%$ \\
\hline
\end{tabular}

Source: primary data, 2020

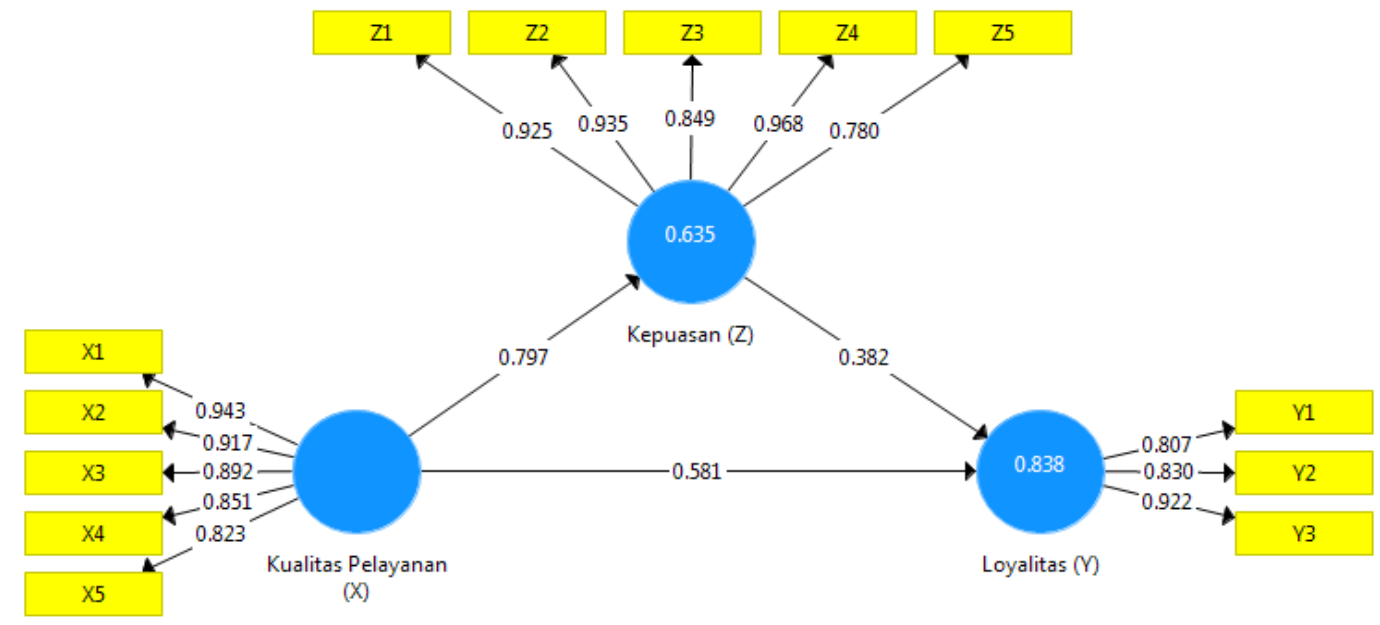

Picture 2. Path diagram

Source: Primary data, 2020

From the results of the measurement model informs that the hospital physical environment indicator (X1) has a loading factor of 0.943 , satisfaction with the time it takes during outpatient visits (Z4) has a loading factor of 0.968 and a desire to reuse services at the hospital (Y3) with a loading factor of 0.922 (Figure 2). This shows that these three indicators are the most dominant indicators in measuring latent variables. T-statistics test results state that service quality has a positive and significant effect on satisfaction $(10,992)$, service quality has a positive and significant effect on loyalty $(3,270)$, satisfaction has a positive and significant effect on loyalty $(2,176)$, service quality has a positive effect and significant on loyalty through satisfaction (1,987).

The results of the Goodnes of Fit Model get the R-Square of the satisfaction variable is worth $63.5 \%$ and the loyalty variable is $83.8 \%$. The diversity of loyalty variables can be explained by the overall model of $94.1 \%$. In the measurement results, the dominant influence between variables is indicated by the total coefficient value. The total coefficient result on the effect of service quality on satisfaction (direct) is 0.797 . The total coefficient on the effect of service quality on loyalty (direct) is 0.581 . The total coefficient result on the effect of satisfaction on loyalty is 0.382 (direct). On the effect of service quality on loyalty through patient satisfaction (indirect) the total coefficient result is 0.886 . The total effect value is the largest compared to the total effect value of the other variables.

Effect of Service Quality on Satisfaction 
The results of hypothesis testing indicate that it has a significant positive effect on satisfaction. The results showed that as many as $71.1 \%$ of respondents admitted to agreeing with the quality of outpatient services and $9.1 \%$ disagreeing with the quality of outpatient services. In the satisfaction assessment, $71.8 \%$ of respondents rated it as satisfied, but $15.5 \%$ of respondents considered it less satisfied.

The most satisfied ratings were on patient interactions with doctors and nurses. In accordance with the research of Fatima, et al (2018) the existence of two-way communication between health workers and patients will increase patient satisfaction, because patients will get clear information about the disease suffered and health workers are willing to listen to patient complaints about their illness and provide solutions according to the the patient expected.

The most unsatisfied assessments were the waiting time at outpatient registration and the waiting time for outpatient examinations. This is in accordance with the research conducted by Liu (2019) who obtained low assessment results on the indicator of waiting time for outpatient services due to the large number of patient visits per day and the availability of health workers (doctors) which is not proportional to the number of patients visiting every day. . The magnitude of the influence of service quality on satisfaction is obtained through the results of T-statistics, namely 10,992. This implies that the better the quality of service provided by the hospital, the patient will feel satisfied (Shabbir, Asma; Malik 2016)

\section{Effect of Service Quality on Loyalty}

The results of testing the hypothesis of the effect of service quality on patient loyalty indicate a significant positive effect of service quality on patient loyalty. The results showed that $65.34 \%$ of respondents agreed to three indicators of loyalty, namely positive word of mouth about services at the hospital, recommending services at the hospital to others and a desire to reuse services at the hospital. The results showed that the most loyalty ratings were positive word of mouth about services at the hospital, which was $70 \%$ and there was a desire to reuse services at the hospital by $64.4 \%$.

The desire to return to using outpatient services at X Hospital was due to the belief in outpatient services at X Hospital, which was shown in the results of the study as much as $71.7 \%$ of respondents agreed with the quality of outpatient services at X Hospital. This is consistent with the research of Yarmen, et al. al (2016) stated that a patient's trust in service quality will affect the desire to return to using health services in hospitals, because services in hospitals are very risky for ethical violations and other risks that affect patient safety.

The magnitude of the influence of quality on loyalty based on the results of $T$ statistics is 3,270. In accordance with research by Arab, et al (2012) stated that there was a strong influence on patient experience regarding service quality on the desire to reuse health services. The results of research on the effect of service quality on patient loyalty show that the better the quality of service, the more loyal the patient will be to services at the hospital. 


\section{The Effect of Satisfaction on Loyalty}

The results of hypothesis testing indicate that patient satisfaction has a significant positive effect on loyalty. The results showed the number of respondents who were satisfied in the satisfaction assessment was $71.85 \%$ and the number of respondents who were loyal in the loyalty assessment was $65.34 \%$. In the satisfaction assessment, the most patients felt satisfied when interacting with doctors and nurses, which was as much as $80 \%$. The greatest loyalty assessment is positive word of mouth about services in the hospital and the desire to reuse services. This is in accordance with the study of Huang, et al (2019) which states that the results of providing health services to patients, patient satisfaction, patient trust, and patient commitment related to treatment in health services will affect patient loyalty. The results of research on the effect of satisfaction on loyalty show that there is an effect of satisfaction on loyalty. The magnitude of the effect of satisfaction on loyalty based on the measurement of T-statistics is 2.176. This shows that the higher the level of satisfaction, the more loyal it is.

\section{Effect of Service Quality on Loyalty through Satisfaction}

The results of hypothesis testing indicate that there is a significant effect of service quality on loyalty through satisfaction. The better the quality of service, the higher the level of satisfaction and through a high level of satisfaction will result in loyalty. The result of measurement of T-statistics is 1.987 . Based on the results of the total coefficient assessment, it was obtained a number of 0.883 , which indicates that the indirect effect in this study is the most dominant influence. In accordance with research conducted by Sadeh (2017), it is revealed that improving service quality can increase satisfaction and loyalty. In a study conducted by Fatima et al (2018), there is a relationship between the quality of health services and patient satisfaction which will result in patient loyalty in accordance with the expectations of the hospital. This is in accordance with the results of research by Shabir et al (2016) which revealed that patient satisfaction is a link in the relationship between service quality and loyalty.

\section{Characteristics of Respondents on Service Quality, Satisfaction and Loyalty}

In this study, the characteristics of the respondents were not examined directly so that in determining the relationship or the amount of influence on satisfaction and loyalty, it could not be measured. Theoretically, in a study conducted by Naidu (2009) there is a close relationship between the level of satisfaction and loyalty based on social demographics which includes age, education, health status, marital status and social status. Respondents who are female tend to be more satisfied and loyal with the quality of service, especially with regard to facilities at the hospital, than respondents who are male. In terms of age characteristics, older 
respondents are more likely to feel satisfied and loyal with the quality of service in the hospital than younger respondents.

In this study, it was found that $43.3 \%$ of general patients had primary school education. Educational status also affects the level of satisfaction and loyalty to services. In a study conducted by Al-Borie, et al (2011) it was revealed that the latest educational status affects satisfaction because it can measure a person's level of knowledge and ability to make medical decisions. So that the better a person's last educational status, the better it will be in making medical decisions and receiving health-related information. However, the results of this study show different data, namely the number of respondents with primary school education status is more than other higher education statuses. This is in accordance with research conducted by Chandra, et al (2019) which obtained $84.3 \%$ of respondents who were satisfied were those with low education. Patients with low education tend to have low expectations and desires related to services in the hospital so that patients with low education tend to feel satisfied quickly compared to patients with high education (Kumar 2016).

The results of the study found that as many as $30 \%$ of respondents had a job status as private employees. Job status also affects patient satisfaction and loyalty to services at the hospital. In Al-Borie's research, et al (2011) suggested that patients who work as private employees and entrepreneurs have a higher level of satisfaction than patients who work as civil servants and students. This is because the amount of income earned as private employees and entrepreneurs is higher than civil servants and students, making it easier for patients to access all health facilities according to patient needs and decide to use the general payment method or use insurance.

The number of visits also affects the level of satisfaction and loyalty. The results of the study found that the number of visits more than 3 times was 55\%. In accordance with Chandra's research, et al (2019) stated that patients who visited more than 3 times were more satisfied than patients who had only visited once. This is because there has been a good relationship and good communication between doctors and patients when patients visit the hospital more than three times, thereby increasing patient satisfaction and loyalty.

\section{CONCLUSION}

Based on the research results, it is concluded that the results of hypothesis testing for each variable indicate that there is a significant positive effect. From the research results that indicate the existence of an assessment of "disagree" and "less satisfied" on each variable measured, namely the variable quality of service, satisfaction and loyalty is a reference for hospitals to make improvements in service quality in order to increase patient satisfaction and loyalty. Therefore, Hospital X needs to make improvements or improved quality of service by way of improve and clicking evaluation on the waiting time of registration and examination in outpatients with distinguishing registration booth online and registration onsite, improve the quality of services through the neighborhood outpatient 
particular order building hospitals and outpatient seemed well maintained, evalution availability of health workers (doctors and nurses) in the face of patient visits so that the quality of services and communication between health workers with patient maintained properly, do a patient satisfaction surveys on a regular basis to distinguish surveys for general patients and insurance patients.

\section{REFERENCE}

Al-borie, Hussein M. 2011. "Patients' Satisfaction of Service Quality in Saudi Hospitals : A SERVQUAL Analysis." International Journal of Health Care Quality Assurance 26(1): 2030.

Alryalat, Saif Aldeen, Wesam Ahmad, Mahmoud Abu-abeeleh, and Quality Assurance. 2019. "Factors Affecting Patient's Satisfaction in Outpatient Clinics in Jordan: CrossSectional Study." Journal of Hospital Management and Health Policy 3(2): 1-6.

Arab, M et al. 2012. "The Effect of Service Quality on Patient Loyalty : A Study of Private Hospitals in Tehran , Iran.” 41(9): 71-77.

Chandra, Swastika, Paul Ward, and Masoud Mohammadnezhad. 2019. "Factors Associated With Patient Satisfaction in Outpatient Department of Suva Sub-Divisional Health Center , Fiji , 2018 : A Mixed Method Study." Frontiers in Public Health 7(July): 1-10.

Fatima, Taqdees, Shahab Alam Malik, and Asma Shabbir. 2018. "Hospital Healthcare Service Quality, Patient Satisfaction and Loyalty: An Investigation in Context of Private Healthcare Systems." International Journal of Quality and Reliability Management 35(6): $1195-1214$.

Fitriani, Sri. 2014. "Pengaruh Kualitas Pelayanan Terhadap Loyalitas Melalui Kepuasan Pasien Pengguna BPJS Di Rawat Inap RSUD Dr. Moewardi.”

Fufa, Bikila Dereje; Negao Enkutatash Befikadu. 2019. "Satisfaction of Outpatient Service Consumers and Associated Factors Towards the Health Service Given at Jimma Medical Center, South West Ethiopia.” Dove Press journal: Patient Related Outcome Measure 10: 347-54.

Huang, Chih-hsuan, Hsin-hung Wu, Yii-ching Lee, and Li Li. 2019. "What Role Does Patient Gratitude Play in the Relationship Between Relationship Quality and Patient Loyalty?" (1018).

Johnson, Dana M., Roberta S. Russell, and Sheneeta W. White. 2016. "Perceptions of Care Quality and the Effect on Patient Satisfaction." International Journal of Quality and Reliability Management 33(8): 1202-29.

Kumar, Jitender. 2016. "Patient Satisfaction in Out Patient Departments ( OPDs ): An Investigative Study in Government Hospitals of Haryana." 6(2).

Liu, Shiyang, and Yuanli Liu. 2019. "How Perceived Quality of Care Affects Outpatient Satisfaction in China: A Cross-Sectional Study of 136 Tertiary Hospitals." The Journal of Health Care Organization, Provision, and Financing The Journal of Health Care Organization, Provision, and Financing 56: 1-8.

Mohd, Surg Lt Cdr Athar, and Brig Abhijit Chakravarty. 2014. "Patient Satisfaction with Services of the Outpatient Deprtment." Medical Journal Armed Forces India 70: 237-42. 
Naidu, Aditi. 2009. "Factors Affecting Patient Satisfaction and Healthcare Quality." International Journal of Health Care Quality Assurance 22(4): 366-81.

Puspitasari, Mei Gawati, and Mochamad Edris. 2011. "Pengaruh Kualitas Layanan Terhadap Loyalitas Dengan Mediasi Kepuasan Pasien Rawat Inap Pada Keluarga Sehat Hospital Pati." Jurnal Analisis Manajemen 5(2): 49-62.

Raposo, Mário Lino, Helena Maria Alves, and Paulo Alexandre Duarte. 2009. "Dimensions of Service Quality and Satisfaction in Healthcare: A Patient's Satisfaction Index." Service Business 3(1): 85-100.

Sadeh, Ehsan. 2017. “Interrelationships among Quality Enablers, Service Quality, Patients” Satisfaction and Loyalty in Hospitals".” TQM Journal 29(1): 101-17.

Shabbir, Asma; Malik, Shahab Alam. 2016. "Measuring Patients” Healthcare Service Quality Perceptions, Satisfaction, and Loyalty in Public and Private Sector Hospitals in Pakistan".” The International Journal of Quality $\mathcal{E}$ Reliability Management 33(5): 538-57.

Supartiningsih, Solichah. 2017. "Kualitas Pelayanan dan Kepuasan Pasien Rumah Sakit: Kasus Pada Pasien Rawat Jalan.” Jurnal Medicoeticolegal dan Manajemen Rumah Sakit 6(1): 9-15.

Yarmen, Medi et al. 2016. "Investigating Patient Loyalty: An Integrated Framework for Trust, Subjective Norm, Image, and Perceived Risk (a Case Study in Depok, Indonesia).” International Journal of Quality and Service Sciences 8(2): 179-96. 